\title{
Silicon accumulation and its effect on agricultural traits and anthracnose incidence in lignocellulosic sorghum ${ }^{1}$
}

\author{
Diego Tolentino de Lima², Marcus Vinicius Sampaio², \\ Carlos Juliano Brant Albuquerque ${ }^{3}$, Hamilton Seron Pereira ${ }^{2}$, Weslei Geraldo Martins ${ }^{4}$
}

\begin{abstract}
Silicon $(\mathrm{Si})$ accumulation in plants may reduce yield losses by inducing resistance to both abiotic and biotic stresses. This study aimed to evaluate the Si accumulation by lignocellulosic sorghum (Sorghum bicolor) in a greenhouse experiment, as well as the effect of its application on agricultural traits and on the induction of resistance against anthracnose (Colletotrichum sublineolum) in a field experiment. Sixteen sorghum genotypes were evaluated in a greenhouse for their response to silicate fertilization, receiving either $0 \mathrm{~kg} \mathrm{ha}^{-1}$ or $261 \mathrm{~kg} \mathrm{ha}^{-1}$ of Si, measuring the Si concentration in the sorghum shoots. Four genotypes that were responsive to $\mathrm{Si}$ fertilization were tested in the field, receiving either $0 \mathrm{~kg} \mathrm{ha}^{-1}$ or $400 \mathrm{~kg} \mathrm{ha}^{-1}$ of $\mathrm{Si}$, being evaluated the $\mathrm{Si}$ concentration on the leaves, plant height, lodging percentage, anthracnose disease severity, grain yield and plant fresh and dry matter. The response of sorghum to Si fertilization in the greenhouse varied with the genotype and, of the 16 genotypes evaluated, 12 were responsive, accumulating more $\mathrm{Si}$ after the fertilization with this element. All four genotypes tested in the field were responsive, but no effect of Si was observed on grain yield or on sorghum fresh and dry matter production. However, the soil Si application reduced the plant lodging and anthracnose severity ratings in sorghum.
\end{abstract}

KEYWORDS: Colletotrichum sublineolum, Sorghum bicolor L. Moench., silicate fertilization.

\section{INTRODUCTION}

There is a general need, as non-renewable energy sources become more expensive, to develop renewable energy alternatives. By the year 2050, an increase of about $50 \%$ is expected in the demand for food, forage, biofuels and other agricultural products

\section{RESUMO}

Acúmulo de silício e seu efeito sobre características agronômicas e incidência de antracnose em sorgo lignocelulósico

O acúmulo de silício (Si) nas plantas pode reduzir perdas de produtividade, pela indução de resistência a estresses abióticos e bióticos. Avaliou-se o acúmulo de Si em sorgo lignocelulósico (Sorghum bicolor), em casa-de-vegetação, bem como o efeito da sua aplicação sobre as características agronômicas e indução de resistência à antracnose (Colletotrichum sublineolum), em experimento de campo. Dezesseis genótipos de sorgo foram avaliados em casade-vegetação, quanto à adubação com silicato, recebendo $0 \mathrm{~kg} \mathrm{ha}^{-1}$ ou $261 \mathrm{~kg} \mathrm{ha}^{-1}$ de Si, mensurando-se a concentração de Si na parte aérea do sorgo. Quatro genótipos que responderam à adubação com Si foram testados em campo, com $0 \mathrm{~kg} \mathrm{ha}^{-1}$ ou $400 \mathrm{~kg} \mathrm{ha}^{-1} \mathrm{de}$ $\mathrm{Si}$, avaliando-se a concentração de $\mathrm{Si}$ nas folhas, altura de planta, porcentagem de acamamento, severidade da doença antracnose, rendimento de grãos e matéria fresca e seca da planta. A resposta do sorgo à adubação com Si em casa-de-vegetação variou com o genótipo e, dos 16 genótipos avaliados, 12 foram responsivos, acumulando mais Si após a fertilização com este elemento. Os quatro genótipos testados em campo foram responsivos, mas não foi encontrado efeito do Si sobre a produtividade de grãos ou sobre a produção de matéria fresca e seca do sorgo. No entanto, a aplicação de Si ao solo reduziu o acamamento de plantas e a severidade da antracnose em sorgo.

PALAVRAS-CHAVE: Colletotrichum sublineolum, Sorghum bicolor L. Moench., adubação silicatada.

(Fedoroff \& Cohen 1999, Bruinsma 2011, Hall \& Richards 2013).

Research on renewable energy resources suggests that some lignocellulosic biomass crops may be able to supply raw materials for the production of second generation biofuels (Carlin \& Rossetto 2014). Among these crops are fast growing

1. Received: Jul. 27, 2018. Accepted: Nov. 12, 2018. Published: Mar. 18, 2019. DOI: 10.1590/1983-40632019v4954201.

2. Universidade Federal de Uberlândia, Instituto de Ciências Agrárias, Uberlândia, MG, Brasil.

E-mail/ORCID: diegotolentino10@hotmail.com/0000-0002-4496-1220,mvsampaio@ufu.br/0000-0002-8767-9030, hspereira@ufu.br/0000-0003-2025-9223.

3. Universidade Federal de Minas Gerais, Montes Claros, MG, Brasil. E-mail/ORCID: carlosjuliano@ufmg.br/ 0000-0003-2244-1336.

4. Advanta Sementes, Uberlândia, MG, Brasil.E-mail/ORCID: weslei.martins@advantaseeds.com/0000-0002-2555-8647. 
grasses with high biomass production, such as Sorghum bicolor (L.) Moench (Cardoso et al. 2013).

Sorghum, a plant from the Poaceae family with C4 metabolism, is tolerant to drought, effectively reaching the deeper soil layers in search of available water and, for this reason, is cultivated throughout the world, in tropical semi-arid regions (Doggett 1988, Ramatoulaye et al. 2016). Sorghum grown for lignocellulosic biomass is a relatively new type of sorghum hybrid produced with longer growing periods for higher biomass yield (Olson et al. 2012, Gill et al. 2014).

Because sorghum is considered a good alternative crop, especially in droughty areas, sorghum crops are oftentimes subjected to water deficit stress. Silicon (Si) absorption may be beneficial for plants under water stress (Epstein 1999, Saud et al. 2014). Even though $\mathrm{Si}$ is not considered essential, from a physiological and metabolic standpoint, for plant growth and development, there is evidence that it plays important roles in defending plants against stresses such as drought, herbivore insects and pathogens. One such pathogen is Colletotrichum sublineolum, the causal agent of anthracnose, which is the most important leaf disease in sorghum (Epstein 1999, Resende et al. 2009 and 2013, Luyckx et al. 2017, Bakhat et al. 2018).

Most Poaceae species are considered Si accumulators, including sorghum (Korndörfer \& Lepsch 2001). Silicon accumulation is associated with plant structural features that increase the structural rigidity of tissues and reduce lodging. In addition, Si promotes the formation of more upright leaves, decreasing self-shading, increasing the leaf area (and consequently the photosynthesis efficacy) and plant growth, as well as leading to a higher crop yield (Epstein 1999, Korndörfer \& Lepsch 2001, Hattori et al. 2005, Ahmed et al. 2014, Manivannan \& Ahn 2017).

This study aimed to evaluate the Si accumulation by sorghum in a greenhouse experiment and analyze the effect of Si application to the soil on agricultural traits and on the resistance induction against anthracnose in lignocellulosic sorghum in a field experiment, thus testing the hypothesis that $\mathrm{Si}$ accumulation is dependent on sorghum genotype and that Si soil application may improve crop traits and reduce anthracnose severity.

\section{MATERIAL AND METHODS}

The response of the sorghum genotypes to the $\mathrm{Si}$ fertilization was determined in an experiment carried out in a greenhouse of the Universidade Federal de Uberlândia, in Uberlândia, Minas Gerais state, Brazil, in February 2015. The average maximum temperature within the greenhouse during the experiment was $34.0{ }^{\circ} \mathrm{C}$, while the average minimum was $19.9^{\circ} \mathrm{C}$. Sixteen experimental sorghum genotypes, previously selected for green biomass production, were tested.

A Typic Quartzipsamment soil (USA 1999) ( $81 \%$ of sand, $5 \%$ of silt, $14 \%$ of clay and $3.5 \mathrm{mg} \mathrm{dm}^{-3}$ of Si) was collected and, after amendments to correct the $\mathrm{pH}, \mathrm{Ca}^{2+}$ and $\mathrm{Mg}^{2+}$ levels (base saturation of $60 \%), 6 \mathrm{~kg}$ of soil were placed in 5-L pots and sown with four sorghum seeds per pot. Planting and sidedressing fertilizer applications were made according to Santos et al. (2014a). Thinning was done at five days after the seedling emergence, leaving one seedling per pot.

In this experiment, 16 sorghum genotypes (LE284, LE296, LE280, LE277, LE272, IPA46742, CF15, LE294, LE299, LE300, LE270, LE263, LE268, LE276, LE271 and LE303) were grown in pots, as previously described, and fertilized (or not) with $\mathrm{Si}$, with three replicates for each genotype/ fertilization status, in a completely randomized design. Silicon was provided as liquid potassium silicate $\left(\right.$ Fertisilício $\left.^{\circledR}\right)$, containing $12 \%$ of total Si and $12 \%$ of $\mathrm{K}_{2} \mathrm{O}$, with a density of $1.39 \mathrm{~g} \mathrm{~cm}^{-3}$. To avoid a potassium over-dose, the fertilizer was diluted in distilled water, to extract the potassium in a cation exchange resin. The resulting solution, containing only silicon $(0.0072 \%$ of $\mathrm{Si})$, was used for daily manual watering of the treatments, for 30 days, resulting in a total of $4.5 \mathrm{~L}$ of solution, corresponding to $261 \mathrm{~kg} \mathrm{ha}^{-1}$ of Si.

Seedlings were cut at the root collar, at 30 days after the emergence, to harvest the shoots. This development stage was selected because, according to Magalhães et al. (2000), the differentiation from the vegetative growth (leaves) to the reproductive one (panicle) occurs at about this stage in sorghum plants, allowing to determine the total number of leaves and the potential size of the panicle.

The sorghum shoots were dried in a forced air oven at $65{ }^{\circ} \mathrm{C}$, until a constant weight, and ground to determine the $\mathrm{Si}$ contents (Korndörfer et al. 2004). The responsiveness of the genotypes was 
determined by comparing the Si concentration in the fertilized treatment with that in the unfertilized one. Meanwhile, the varieties with the greatest Si concentration among those in the unfertilized treatment were labeled as Si efficient.

A field experiment with high Si-uptake sorghum varieties was done at the Capim Branco experimental farm $\left(18^{\circ} 52^{\prime} 55^{\prime}\right.$ "66S, 48²0'28" $21 \mathrm{~W}$ and altitude of $820 \mathrm{~m}$ ), in Uberlândia, in a clayey ( $50 \%$ of clay) Rhodic Acrudox soil (USA 1999), with a low $\mathrm{Si}$ content $\left(5.5 \mathrm{mg} \mathrm{kg}^{-1}\right)$. This naturally low $\mathrm{Si}$ level provided the opportunity to assess the effect of the addition of further Si to the soil, according to Korndörfer et al. (1999). The experiment was repeated twice, with sorghum sowings in January and February 2016, 40 days apart from one another, with identical management and response evaluation. Rainfall and average temperature data were recorded for the duration of the experiment (Figure 1).

The selection of sorghum varieties for the field trial was based on the greenhouse experiment. Four sorghum varieties (LE268 and LE276 - among the most responsive varieties, in terms of silicon update; LE299 and LE270 - among the least responsive varieties, in terms of silicon uptake), two Si doses $\left(0 \mathrm{~kg} \mathrm{ha}^{-1}\right.$ or $\left.400 \mathrm{~kg} \mathrm{ha}^{-1}\right)$ and two sowing dates, for a total of 16 treatments, were used in the field experiment, in a randomized block design (4 genotypes x 2 Si doses $x 2$ sowing dates $x 4$ blocks).

The silicon-treated plots received Agrosilício Plus ${ }^{\circledR}$ Agronelli (powder formulation with $10.5 \%$ of total $\mathrm{Si}, 35 \%$ of $\mathrm{CaO}$ and $10 \%$ of $\mathrm{MgO}$ ) at the $\mathrm{Si}$ dose equivalent to $400 \mathrm{~kg} \mathrm{ha}^{-1}$, manually incorporated into the first $20 \mathrm{~cm}$ of the soil using a hoe. Treatments with no Si fertilization received dolomitic limestone Ercal $^{\circledR}(37-38 \%$ of $\mathrm{CaO}$ and $8-10 \%$ of $\mathrm{MgO})$ to equilibrate the amounts of $\mathrm{Ca}$ and $\mathrm{Mg}$, using the same amounts $\left(3,809 \mathrm{~kg} \mathrm{ha}^{-1}\right)$ of lime and Agrosilício, in both situations.

The plots (area of $10.0 \mathrm{~m}^{2}$ ) consisted of four 5-m long rows, with the two central rows being used for observations, disregarding the $0.5 \mathrm{~m}$ sections at the ends of each row. The four sorghum genotypes selected for the field trials were sown at 30 days after the application of soil treatments, with rows spaced $0.5 \mathrm{~m}$ apart, leaving five plants per meter after thinning, for a population of 100,000 plants per hectare.

Fertilization (at planting and later as sidedressing) was done according to Santos et al. (2014a). Weeds were controlled before sowing with glyphosate, at pre-emergence with atrazine applied in the furrow at the time of sowing, and during the cropping cycle by hoeing. No insecticides or fungicides were applied.

One flag leaf from each of the six plants from each genotype was collected at full flowering (50\% of panicles with open flowers) to determine the $\mathrm{Si}$ concentration, using the same methodology used in the greenhouse experiment.

When the grain reached the physiological maturity, about 110-115 days after sowing, the

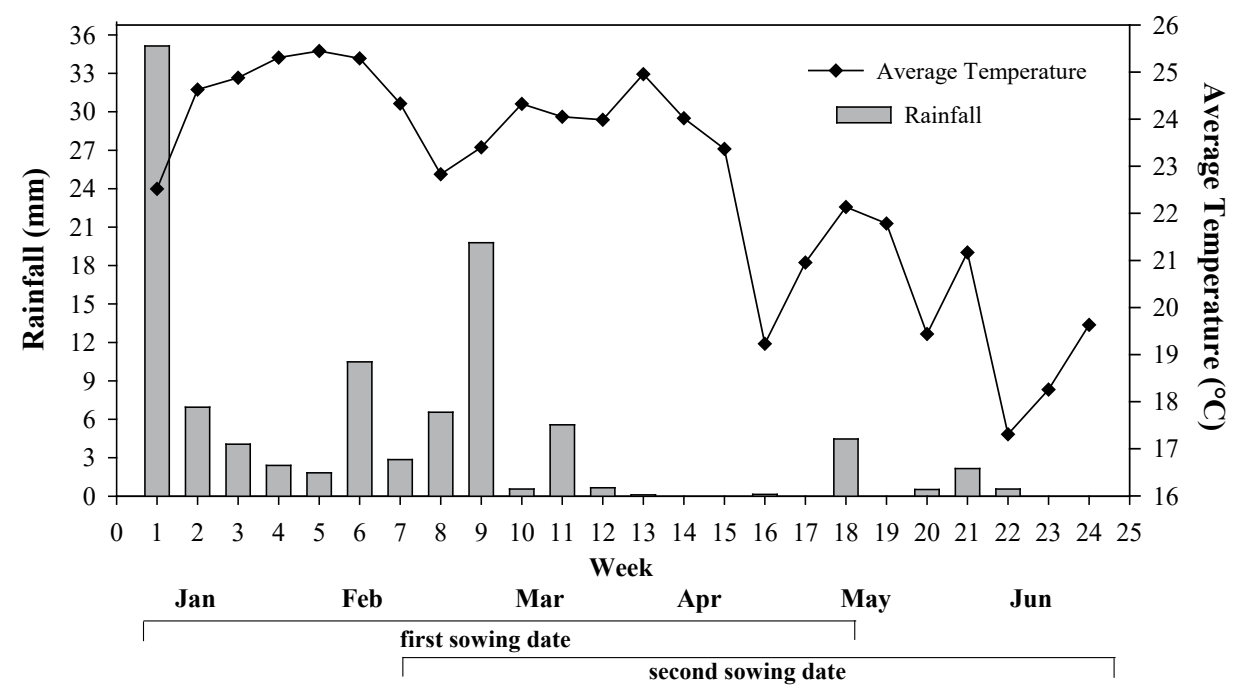

Figure 1. Weekly average temperature and accumulated rainfall during the experiments. Source: weather station at the Capim Branco experimental farm, in Uberlândia, Minas Gerais state, Brazil, in 2016. 
plant height $(\mathrm{cm})$ and plant lodging (\%), along with anthracnose incidence (C. sublineolum), were evaluated, based on a severity rating scale using a visual evaluation with $1=0-3 \% ; 2=3-6 \% ; 3=$ $6-12 \% ; 4=12-25 \%$; and $5=25-50 \%$ of the leaf area being diseased (Horsfall \& Barratt 1945). The panicles of 10 plants in the sampled area were collected at random to estimate the grain yield, and all the plants in the sampled area were harvested and weighed to estimate the fresh matter production. Subsequently, plants were shredded, and a sample was collected and dried in an oven, to estimate the dry matter.

The normality of residues was confirmed by the Shapiro-Wilk's test $(p=0.01)$ and the homogeneity of variances by the Levene's test $(p=0.05)$. For the greenhouse experiment, data on $\mathrm{Si}$ concentration were analyzed with two-way Anova, considering the sorghum genotypes, the presence or absence of $\mathrm{Si}$ and their interaction as independent variables, with three replications of each treatment. The Si concentration in the plants among the genotypes was grouped by the Scott-Knott test $(p=0.05)$.

For the field experiment, the Si concentration in the flag leaf, plant height, lodging percentage, anthracnose severity ratings, grain yield and fresh and dry matter of the field grown sorghum were analyzed by three-way Anova (conjoint analysis), considering the sorghum genotypes, the presence or absence of $\mathrm{Si}$, the sowing date and their interactions as independent variables. Whenever significant effects were observed, the averages of specific treatments were compared by the Tukey test $(p=0.05)$.

\section{RESULTS AND DISCUSSION}

A significant interaction was found between genotype and soil Si application for the concentration of $\mathrm{Si}$ in the dry biomass of sorghum plants in the greenhouse. The genotypes LE296, LE280, LE277, LE272 and IPA46742 were more efficient in Si uptake than LE294, LE299, LE300, LE270, LE268 and LE276, reaching the highest Si content when the soil was not fertilized with this element (Table 1). Out of the 16 genotypes evaluated, 12 were responsive to Si fertilization, having a greater Si concentration after the fertilization with this element, while four genotypes did not respond to the Si fertilization (Table 1). Among the responsive genotypes, LE284, LE277, LE263, LE268, LE276 and LE303 accumulated more Si after fertilization (Table 1).
Ten genotypes (LE284, LE296, LE280, LE277, LE272, IPA46742, CF15, LE263, LE271 and LE303) with no fertilization, and all the 16 genotypes after fertilization, accumulated $\mathrm{Si}$ in concentrations above $1 \%$ of the plant dry biomass, agreeing with what was expected for plants classified as Si accumulators (Ma \& Takahashi 2002) and with other studies with sorghum (Lux et al. 2002, Hattori et al. 2005, Resende et al. 2009, Ahmed et al. 2014).

It is known that the $\mathrm{Si}$ concentration varies among genotypes within a given species, although, in general, such variation is not as pronounced as that between species (Deren 2001, Lux et al. 2002, Ma \& Takahashi 2002, Hodson et al. 2005, Ahmed et al. 2014). Four genotypes were selected for the field experiment among those that were responsive to $\mathrm{Si}$ addition, two that most accumulated Si (LE268 and LE276) and two that least accumulated Si (LE299 and LE270).

No interactions were observed among the genotype, Si application rate or sowing date for the Si content in sorghum leaves in the field experiment. However, the soil fertilization with $400 \mathrm{~kg} \mathrm{ha}^{-1}$ of Si resulted in a greater concentration of leaf Si than in plants in unfertilized treatment plots, and a greater leaf $\mathrm{Si}$ concentration in sorghum was also detected

Table 1. Silicon ( $\mathrm{Si}$ ) concentration in sorghum plants (percentage average \pm standard error), at 30 days after the emergence, under greenhouse conditions.

\begin{tabular}{lcc}
\hline \multicolumn{1}{c}{ Genotypes } & With Si & Without $\mathrm{Si}$ \\
\hline LE284 & $2.10 \pm 0.16 \mathrm{Aa}^{*}$ & $1.36 \pm 0.17 \mathrm{Bb}$ \\
LE296 & $1.57 \pm 0.25 \mathrm{Ba}$ & $1.95 \pm 0.07 \mathrm{Aa}$ \\
LE280 & $1.80 \pm 0.13 \mathrm{Ba}$ & $1.78 \pm 0.02 \mathrm{Aa}$ \\
LE277 & $2.28 \pm 0.13 \mathrm{Aa}$ & $1.72 \pm 0.08 \mathrm{Ab}$ \\
LE272 & $1.69 \pm 0.12 \mathrm{Ba}$ & $1.82 \pm 0.01 \mathrm{Aa}$ \\
IPA46742 & $2.11 \pm 0.21 \mathrm{Aa}$ & $1.83 \pm 0.07 \mathrm{Aa}$ \\
CF15 & $1.93 \pm 0.12 \mathrm{Ba}$ & $1.37 \pm 0.32 \mathrm{Bb}$ \\
LE294 & $1.95 \pm 0.02 \mathrm{Ba}$ & $0.89 \pm 0.12 \mathrm{Cb}$ \\
LE299 & $1.85 \pm 0.13 \mathrm{Ba}$ & $0.93 \pm 0.09 \mathrm{Cb}$ \\
LE300 & $1.74 \pm 0.01 \mathrm{Ba}$ & $0.91 \pm 0.14 \mathrm{Cb}$ \\
LE270 & $1.83 \pm 0.16 \mathrm{Ba}$ & $0.82 \pm 0.04 \mathrm{Cb}$ \\
LE263 & $2.30 \pm 0.08 \mathrm{Aa}$ & $1.10 \pm 0.12 \mathrm{Bb}$ \\
LE268 & $2.24 \pm 0.26 \mathrm{Aa}$ & $0.78 \pm 0.04 \mathrm{Cb}$ \\
LE276 & $2.28 \pm 0.12 \mathrm{Aa}$ & $0.98 \pm 0.23 \mathrm{Cb}$ \\
LE271 & $1.92 \pm 0.06 \mathrm{Ba}$ & $1.21 \pm 0.12 \mathrm{Bb}$ \\
LE303 & $2.26 \pm 0.15 \mathrm{~A} \mathrm{a}$ & $1.29 \pm 0.25 \mathrm{Bb}$ \\
\hline CV $(\%)$ & &
\end{tabular}

$\mathrm{CV}(\%)=15.52$

* Averages followed by different capital letters in the columns and lower case in the rows are different by the Scott-Knott $(p=0.05)$ and $F(p=0.05)$ tests, respectively. $\mathrm{CV}=$ coefficient of variation. 
from the first sowing date than in sorghum from the second one (Table 2).

All four genotypes evaluated in the field were responsive to Si fertilization, and their leaf $\mathrm{Si}$ concentrations did not differ significantly from each other at harvest (Table 2). Thus, they did not maintain the pattern of the two most (LE268 and LE276) and the two least (LE299 and LE270) responsive ones, as observed in the greenhouse. The average leaf $\mathrm{Si}$ concentration was less than $1 \%$, corroborating the results of Moraes \& Carvalho (2002) and Santos et al. (2014b). However, it was smaller than that found in the greenhouse with no Si fertilization. Silicon is retained (adsorbed) by iron and aluminum oxides in the clay fraction of the soil (Obihara \& Russel 1972); thus, less $\mathrm{Si}$ absorption was observed in field-grown plants than in the greenhouse, since the field plants were grown in a clayey soil. Moreover, water is fundamental for fertilizer solubilization (Calonego et al. 2012), and the constant water availability and the high solubility of the Si source used in the greenhouse also may explain the greater absorption of this element in the greenhouse than in the field.

The percentage of lodged plants was smaller after the application of $400 \mathrm{~kg} \mathrm{ha}^{-1}$ of Si than in the non-fertilized treatment (Table 3). A significant interaction was found between Si fertilization and genotype for plant height, and soil Si fertilization increased the average height only in LE299, in comparison with the non-fertilized treatment.

Table 2. Leaf silicon ( $\mathrm{Si}$ ) concentration in sorghum plants (percentage average \pm standard error), as a function of Si fertilization, in two sowing dates in the field.

\begin{tabular}{|c|c|c|c|c|}
\hline \multirow{2}{*}{ Sowing date } & \multirow{2}{*}{ Genotype } & \multicolumn{2}{|c|}{ Si dose $\left(\mathrm{kg} \mathrm{ha}^{-1}\right)$} & \multirow{2}{*}{ Average $\pm \mathrm{SE}$} \\
\hline & & 0 & 400 & \\
\hline \multirow{5}{*}{ First } & LE268 & $0.67 \pm 0.08$ & $0.94 \pm 0.14$ & \multirow{4}{*}{$0.93 \pm 0.05 \mathrm{~A}$} \\
\hline & LE276 & $0.85 \pm 0.03$ & $1.21 \pm 0.23$ & \\
\hline & LE270 & $0.79 \pm 0.10$ & $1.02 \pm 0.16$ & \\
\hline & LE299 & $0.93 \pm 0.13$ & $1.02 \pm 0.13$ & \\
\hline & Average & $0.81 \pm 0.05$ & $1.05 \pm 0.08$ & \multirow{5}{*}{$0.56 \pm 0.04 \mathrm{~B}$} \\
\hline \multirow{5}{*}{ Second } & LE268 & $0.48 \pm 0.07$ & $0.54 \pm 0.07$ & \\
\hline & LE276 & $0.62 \pm 0.07$ & $0,69 \pm 0.23$ & \\
\hline & LE270 & $0.44 \pm 0.04$ & $0.44 \pm 0.02$ & \\
\hline & LE299 & $0.59 \pm 0.06$ & $0.70 \pm 0.14$ & \\
\hline & Average & $0.53 \pm 0.03$ & $0.59 \pm 0.07$ & \\
\hline \multicolumn{2}{|l|}{ General average } & $0.67 \pm 0.03 b^{*}$ & $0.82 \pm 0.05 \mathrm{a}$ & \\
\hline
\end{tabular}

Table 3. Averages ( \pm standard error) of the first and second sowing dates for lodging, plant height and anthracnose severity, for sorghum genotypes with or without silicon (Si) field application.

\begin{tabular}{|c|c|c|c|c|}
\hline \multirow{2}{*}{ Variable } & \multirow{2}{*}{ Genotypes } & \multicolumn{2}{|c|}{ Si dose $\left(\mathrm{kg} \mathrm{ha}^{-1}\right)$} & \multirow[t]{2}{*}{ Average } \\
\hline & & 0 & 400 & \\
\hline \multirow{4}{*}{ Lodging } & LE268 & $4.00 \pm 1.69$ & $1.50 \pm 0.73$ & $2.75 \pm 0.95 \mathrm{a}$ \\
\hline & LE276 & $3.14 \pm 1.03$ & $1.50 \pm 1.50$ & $2.32 \pm 0.90 \mathrm{a}$ \\
\hline & LE270 & $4.00 \pm 2.00$ & $1.50 \pm 0.73$ & $2.75 \pm 1.08 \mathrm{a}$ \\
\hline & LE299 & $1.50 \pm 1.05$ & $1.50 \pm 1.05$ & $1.50 \pm 0.72 \mathrm{a}$ \\
\hline$(\%)$ & Average & $3.16 \pm 0.74 \mathrm{~A}^{*}$ & $1.50 \pm 0.50 \mathrm{~B}$ & \\
\hline \multirow[b]{2}{*}{ Height } & LE268 & $105.63 \pm 5.63 \mathrm{cA}$ & $109.38 \pm 6.37 \mathrm{dA}$ & \\
\hline & LE276 & $182.05 \pm 16.96 \mathrm{aA}$ & $181.88 \pm 15.00 \mathrm{aA}$ & \\
\hline \multirow{2}{*}{$(\mathrm{cm})$} & LE270 & $130.00 \pm 10.98 \mathrm{bA}$ & $130.38 \pm 12.20 \mathrm{cA}$ & \\
\hline & LE299 & $129.38 \pm 11.24 \mathrm{bB}$ & $147.50 \pm 8.66 \mathrm{bA}$ & \\
\hline \multirow{5}{*}{ Anthracnose } & LE268 & $3.50 \pm 0.19$ & $3.38 \pm 0.18$ & $3.44 \pm 0.13 \mathrm{a}$ \\
\hline & LE276 & $2.10 \pm 0.34$ & $1.88 \pm 0.30$ & $1.99 \pm 0.22 \mathrm{c}$ \\
\hline & LE270 & $2.88 \pm 0.23$ & $2.75 \pm 0.25$ & $2.81 \pm 0.16 b$ \\
\hline & LE299 & $3.25 \pm 0.25$ & $2.63 \pm 0.18$ & $2.94 \pm 0.17 b$ \\
\hline & Average & $2.93 \pm 0.16 \mathrm{~A}$ & $2.66 \pm 0.15 \mathrm{~B}$ & \\
\hline
\end{tabular}


The genotype with the greatest height in both $\mathrm{Si}$ treatments was LE276, while that with the least height was LE268 (Table 3).

The average rating for anthracnose severity was lower in Si-treated plants than in those with no fertilization (Table 3), suggesting the occurrence of Si-induced resistance in sorghum plants against anthracnose. Regardless of the genotype evaluated, the disease severity rating decreased in plants fertilized with Si. Silicon is known for inducing resistance against abiotic and biotic stresses (Epstein 1999), including some economically important diseases in rice, wheat, barley, rye, maize, cucumber, grape and strawberry, that can be effectively controlled by fertilizing plants with Si (Datnoff et al. 2007). Silicon absorption by susceptible cultivars may increase the resistance level to that of a resistant one grown with no Si fertilization, resulting in a similar control of leaf lesions (Kim et al. 2002, Resende et al. 2009). Increasing $\mathrm{Si}$ doses in a resistant sorghum genotype and another susceptible genotype to anthracnose demonstrated by disease severity ratings the effect of $\mathrm{Si}$ in reducing the disease severity for both genotypes (Santos et al. 2014b), similarly to what was observed in the present study.

There were significant differences in the disease rating with sowing date and genotypes, with no interaction between the factors. Disease severity ratings for the first sowing date $(2.35 \pm$ $0.15)$ were smaller $(\mathrm{p}<0.05)$ than for the second date $(3.25 \pm 0.11)$. LE276 $(1.99 \pm 0.22)$ presented the lowest anthracnose severity rating, followed by LE299 (2.94 \pm 0.17$)$ and LE270 (2.81 \pm 0.16$)$, which were intermediate, while LE268 $(3.44 \pm 0.13)$ had the greatest disease severity $(\mathrm{p}<0.05)$, regardless of the Si dose and sowing date.

No effect of Si fertilization was found in the plant fresh and dry matter and sorghum grain yield. The average plant height, fresh and dry matter, and grain yield were greater for the first sowing date than for the second one, for all the four genotypes $(p<0.05)$. Regardless of the sowing date, the plant height and fresh and dry matter were the greatest for LE276 and the least for LE268, while LE299 and LE270, in general, presented intermediate values. However, differences in grain yield were observed only for the first sowing date, with LE276 having the greatest yield, while LE270 was the least productive, and LE268 and LE299 had intermediate values. Yield for the second date was greatly reduced by drought (to less than $10 \%$ of the yield from the first date), and consequently all the genotypes performed similarly (Table 4).

The Si accumulation also affects the plant structure, increasing the tissue structure firmness, reducing lodging and plant breaking, besides contributing to a greater crop yield (Epstein 1999, Korndörfer \& Lepsch 2001, Hattori et al. 2005, Ahmed et al. 2014, Manivannan \& Ahn 2017). A reduction in the percentage of lodged sorghum plants was observed in the soil fertilized with Si. Only the genotype LE299 was responsive to Si fertilization, in terms of plant height, presenting shorter plants when this element was not supplied (Table 3). However, in this study, the Si fertilization did not contribute to increases in the fresh and dry matter, nor in grain yield.

The severe water stress endured by plants sown on the second date (Figure 1) was reflected on a reduction in plant height, fresh and dry matter in all the four genotypes, if compared to the first date. Moreover, there was a greater lodging and anthracnose severity, which compounded with the other variables to reduce the grain yield, in relation to the first sowing date (Table 4).

The Si mitigation of the water stress on sorghum was expected, what should result in a greater crop yield, since such an effect on sorghum had been previously reported (Hattori et al. 2005 and 2008, Sonobe et al. 2009). However, in the second sowing date, the water stress was so severe that no positive

Table 4. Averages ( \pm standard error) of fresh matter, dry matter and grain yield for sorghum genotypes in the first and second sowing dates in the field.

\begin{tabular}{|c|c|c|c|}
\hline \multirow{2}{*}{ Variable } & \multirow{2}{*}{ Genotypes } & \multicolumn{2}{|c|}{ Sowing date } \\
\hline & & First & Second \\
\hline \multirow[b]{2}{*}{ Fresh matter } & LE268 & $58.64 \pm 3.49 \mathrm{dA}^{*}$ & $43.95 \pm 1.51 \mathrm{bB}$ \\
\hline & LE276 & $185.84 \pm 5.42 \mathrm{aA}$ & $62.38 \pm 5.41 \mathrm{aB}$ \\
\hline \multirow{2}{*}{$\left(\mathrm{Mg} \mathrm{ha}^{-1}\right)$} & LE270 & $157.25 \pm 3.51 \mathrm{bA}$ & $59.75 \pm 3.35 \mathrm{aB}$ \\
\hline & LE299 & $78.34 \pm 2.88 \mathrm{cA}$ & $49.05 \pm 4.78 \mathrm{abB}$ \\
\hline \multirow[b]{2}{*}{ Dry matter } & LE268 & $18.73 \pm 1.03 \mathrm{cA}$ & $14.77 \pm 0.47 \mathrm{bB}$ \\
\hline & LE276 & $54.80 \pm 2.09 \mathrm{aA}$ & $20.78 \pm 1.78 \mathrm{aB}$ \\
\hline \multirow{2}{*}{$\left(\mathrm{Mg} \mathrm{ha}^{-1}\right)$} & LE270 & $54.21 \pm 1.03 \mathrm{aA}$ & $19.65 \pm 1.13 \mathrm{abB}$ \\
\hline & LE299 & $27.33 \pm 0.99 \mathrm{bA}$ & $16.27 \pm 1.37 \mathrm{abB}$ \\
\hline \multirow{2}{*}{ Grain yield } & LE268 & $4.43 \pm 0.20 \mathrm{bA}$ & $0.29 \pm 0.03 \mathrm{aB}$ \\
\hline & LE276 & $6.21 \pm 0.12 \mathrm{aA}$ & $0.34 \pm 0.03 \mathrm{aB}$ \\
\hline \multirow[t]{2}{*}{$\left(\mathrm{Mg} \mathrm{ha}^{-1}\right)$} & LE270 & $3.38 \pm 0.36 \mathrm{cA}$ & $0.48 \pm 0.05 \mathrm{aB}$ \\
\hline & LE299 & $4.75 \pm 0.25 \mathrm{bA}$ & $0.45 \pm 0.10 \mathrm{aB}$ \\
\hline
\end{tabular}

* Averages followed by different capital letters in the rows and lower case in the columns are different by the $\mathrm{F}(\mathrm{p}=0.05)$ and Tukey $(\mathrm{p}=0.05)$ tests, respectively. 
effects of Si on sorghum were detected, suggesting that such effects can be observed only to a given limit within which plants can still perform their metabolic activities. Another possibility is that there was no sufficient Si content in the plant tissue to induce an anti-stress effect. Although the first sowing did not suffer such a severe water stress and the plants presented a greater leaf Si concentration (Table 2), no effects on crop yield could be attributed to the $\mathrm{Si}$ addition.

\section{CONCLUSIONS}

1. Most of the sorghum genotypes assessed under greenhouse conditions are responsive and accumulate more silicon when fertilized with this element. Responsive genotypes in the greenhouse are also responsive in the field;

2. Silicon addition induces resistance to anthracnose in sorghum, regardless of the sowing date;

3. Fertilization with silicon do not influence grain yield, nor fresh and dry matter in sorghum; however, it reduces plant lodging.

\section{ACKNOWLEDGMENTS}

We would like to thank the Conselho Nacional de Desenvolvimento Científico e Tecnológico (CNPq), Coordenação de Aperfeiçoamento de Pessoal de Nível Superior (Capes) and Fundação de Amparo à Pesquisa do Estado de São Paulo (FAPESP), for the financial support to the INCT-HYMPAR; and Agronelli Insumos Agrícolas and Ercal Calcário, for supporting this research.

\section{REFERENCES}

AHMED, M. et al. Augmenting drought tolerance in sorghum by silicon nutrition. Acta Physiologiae Plantarum, v. 36, n. 2, p. 473-483, 2014.

BAKHAT, H. F. et al. Silicon mitigates biotic stresses in crop plants: a review. Crop Protection, v. 104, n. 1, p. 21-34, 2018.

BRUINSMA, J. The resource outlook to 2050: by how much do land, water use and crop yields need to increase by 2050 ? In: CONFORTI, P. (Ed.). Looking ahead in world food and agriculture: perspectives to 2050. Rome: FAO, 2011. p. 233-278.

CALONEGO, J. C. et al. Calagem e silicatagem em solo incubado com diferentes umidades. Colloquium Agrariae, v. 8 , n. 2 , p. $46-56,2012$.
CARDOSO, W. S. et al. Use of sorghum straw (Sorghum bicolor) for second generation etanol producion: pretreatment and enzymatic hydrolysis. Química Nova, v. 36, n. 5, p. 623-627, 2013.

CARLIN, S. D.; ROSSETTO, R. Biomassa para produção de energia. Pesquisa \& Tecnologia, v. 11, n. 2, p. 1-6, 2014.

DATNOFF, L. E. et al. Silicon and plant disease. In: DATNOFF, L. E.; ELMER, W. H.; HUBER, D. M. (Eds.). Mineral nutrition and plant disease. Saint Paul: American Phytopathological Society, 2007. p. 233-246.

DEREN, C. W. Plant genotype, silicon concentration, and silicon-related responses. In: DATNOFF, L. E.; SNYDER, G. H.; KORNDÖRFER, G. H. (Eds.). Silicon in agriculture. Amsterdam: Elsevier Science, 2001. p. $149-158$.

DOGGETT, H. Sorghum. 2. ed. Harlow: Longman Scientific \& Technical, 1988.

EPSTEIN, E. Silicon. Annual Review of Plant Physiology and Plant Molecular Biology, v. 50, n. 1, p. 641-664, 1999.

FEDOROFF, N. V.; COHEN, J. E. Plants and population: is there time? Proceedings of the National Academy of Sciences of the United States of America, v. 96, n. 11, p. 5903-5907, 1999.

GILL, J. R. et al. Yield results and stability analysis from the sorghum regional biomass feedstock trial. Bioenergy Research, v. 7, n. 3, p. 1026-1034, 2014.

HALL, A. J.; RICHARDS, R. A. Prognosis for genetic improvement of yield potential and water-limited yield of major grain crops. Field Crops Research, v. 143, n. 1, p. 18-33, 2013.

HATTORI, T. et al. Application of silicon enhanced drought tolerance in Sorghum bicolor. Physiologia Plantarum, v. 123, n. 4, p. 459-466, 2005.

HATTORI, T. et al. Silicon application by sorghum through the alleviation of stress-induced increase in hydraulic resistance. Journal of Plant Nutrition, v. 31, n. 8, p. 14821495, 2008.

HODSON, M. J. et al. Phylogenetic variation in the silicon composition of plants. Annals of Botany, v. 96, n. 6, p. 1027-1046, 2005.

HORSFALL, J. G.; BARRATT, R. W. An improved grading system for measuring plant diseases. Phytopathology, v. 35, n. 8 , p. $655,1945$.

KIM, S. G. et al. Silicon-induced cell wall fortification of rice leaves: a possible cellular mechanism of enhanced host resistance to blast. Phytopathology, v. 92, n. 10, p. 1045-1103, 2002. 
KORNDÖRFER, G. H. et al. Análise de silício: solo, planta e fertilizante. Uberlândia: GPSi-ICIAG-UFU, 2004.

KORNDÖRFER, G. H. et al. Avaliação de métodos de extração de silício para solos cultivados com arroz de sequeiro. Revista Brasileira de Ciência do Solo, v. 23, n. 1, p. 101-106, 1999.

KORNDÖRFER, G. H.; LEPSCH, I. Effect of silicon on plant growth and yield. In: DATNOFF, L. E.; KORNDÖRFER, G. H.; SNYDER, G. H. (Eds.). Silicon in agriculture. Amsterdam: Elsevier, 2001. p. 133-147.

LUX, A. et al. Silicification in sorghum (Sorghum bicolor) cultivars with different drought tolerance. Physiologia Plantarum, v. 115, n. 1, p. 87-92, 2002.

LUYCKX, M. et al. Silicon and plants: current knowledge and technological perspectives. Frontiers in Plant Science, v. 8, n. 1, p. $1-8,2017$.

MA, J. F.; TAKAHASHI, E. Soil, fertilizer, and plant silicon research in Japan. Amsterdam: Elsevier Science, 2002.

MAGALHÃES, P. C. et al. Fisiologia da planta de sorgo. Sete Lagoas: Embrapa Milho e Sorgo, 2000.

MANIVANNAN, A.; AHN, Y. K. Silicon regulates potential genes involved in major physiological processes in plants to combat stress. Frontiers in Plant Science, v. 8, n. 1, p. 1-13, 2017.

MORAES, J. C.; CARVALHO, S. P. Indução de resistência em plantas de sorgo Sorghum bicolor (L.) Moench. ao pulgão-verde Schizaphis graminum (Rond., 1852) (Hemiptera: Aphididae) com a aplicação de silício. Ciência e Agrotecnologia, v. 26, n. 6, p. 1185-1189, 2002.

OBIHARA, C. H.; RUSSEL, E. W. Specific adsorption of the silicate and phosphate by soils. Journal of Soil Science, v. 23, n. 1, p. 105-117, 1972.
OLSON, S. N. et al. High biomass yield energy sorghum: developing a genetic model for $\mathrm{C} 4$ grass bioenergy crops. Biofuels Bioproducts Biorefining, v. 6, n. 6, p. 640-655, 2012.

RAMATOULAYE, F. et al. Production and use of sorghum: a literature review. Journal of Nutritional Health \& Food Science, v. 4, n. 1, p. 1-4, 2016.

RESENDE, R. S. et al. Influence of silicon on some components of resistance to anthracnose in susceptible and resistant sorghum lines. European Journal of Plant Pathology, v. 124, n. 3, p. 533-541, 2009.

RESENDE, R. S. et al. Silicon and fungicide effects on anthracnose in moderately resistant and susceptible sorghum lines. Journal of Phytopathology, v. 161, n. 1, p. 11-17, 2013.

SANTOS, C. S. et al. Correção do solo e adubação na cultura do sorgo. Informe Agropecuário, v. 35, n. 278, p. $76-88,2014 a$.

SANTOS, G. R. et al. Severidade de antracnose em folhas de sorgo submetido a doses crescentes de silício. Revista Ciência Agronômica, v. 45, n. 2, p. 403-408, 2014 b.

SAUD, S. et al. Silicon application increases drought tolerance of Kentucky bluegrass by improving plant water relations and morphophysiological functions. The Scientific World Journal, v. 2014, e368694, 2014.

SONOBE, K. et al. Diurnal variations in photosynthesis, stomatal conductance and leaf water relation in sorghum grown with or without silicon under water stress. Journal of Plant Nutrition, v. 32, n. 3, p. 433-442, 2009.

USA. Soil Survey Staff. Soil taxonomy: a basic system of soil classification for making and interpreting soil surveys. Washington, DC: USDA, 1999. 